ACTA THERIOLOGICA

Vol. 29, 6: 63-75, 1984

\title{
A Rapid Summer Decline in a Mountain Hare Population on an Island
}

\section{Anders ANGERBJÖRN \& Björn HJERNQUIST}

\begin{abstract}
Angerbjörn A. \& Hjernquist B., 1984: A rapid summer decline in a mountain hare population on an island. Acta theriol., 29, 6: 63-75 [With 5 Tables \& 6 Figs.].

A mountain hare, Lepus timidus Linnaeus, 1758, population was followed from 1973 to 1978 on Lilla Karlsö island in the Baltic Sweden. Density estimates were first based on direct counts, and later on marking and re-observation of hares. The density was fairly stable at a very high level, about 400 hares on 160 ha, for several years. During the severe winter $1976 / 77$ the number decreased to 162 hares in January, 107 in May and in August less than 10 hares remained. The monthly adult survival rate during the summer was therefore less than 0.75 . In early spring, male hares especially, were in bad condition and probably suffered a higher mortality, while females probably died during early summer. The possible role of food shortage and parasitic infestation is discussed.
\end{abstract}

[Department of Zoology, University of Stockholm, S-106 91 Stockholm (AA); Länsstyrelsen i Stockholms län, Box 22067, S-104 22 Stockholm, Sweden (HB)]

\section{INTRODUCTION}

The mountain hare, Lepus timidus Linnaeus, 1758, normally has low population density on the Swedish mainland, with only a few hares per sq $\mathrm{km}$ (Lindlöf, 1979). The highest density that has been reported on a mainland is 51 hares per sq $\mathrm{km}$ in Scotland (Watson et al., 1973). Conversely, on islands one can find very high densities with more than 300 hares per sq km (Angerbjörn, 1977, 1981; Häkkinen \& Jokinen, 1981). Dramatic decreases on island have been reported earlier (Angerbjörn, 1981; Häkkinen \& Jokinen, 1981), and in these cases mortality has been highest during winter to spring. Studies on other Lepus species also show the highest mortality in winter to spring, both during normal years and years of a rapid decline (Hewson 1965, 1976; Flux, 1970; Abildgard et al., 1972; Keith \& Windberg, 1978). Here, we raport of a mountain hare population that have a normal decline during winter and early spring after a severe winter. However, instead of a recovery during the summer, the population crashed, with the highest mortality measured in June to July. We discuss different factors and their possible role in the dynamics of this island population of the mountain hare. 


\section{STUDY AREA}

Lilla Karlsö island (Fig. 1) with an area of $1.6 \mathrm{sq} \mathrm{km}$, is situated $4.5 \mathrm{~km}$ west of Gotland in the Baltic Sea. Lilla Karlsö island has been influenced by sheep grazing for hundreds of years. This has resulted in a shrub-less grassland pasture with solitary giant trees on the steep stony slopes. The grass (Festuca ovina) dominated vegetation has an annual maximum productivity in early summer (May-June), with the crop varying 0.7-1.6 ton (dry matter) per ha productive area $(80 \%)$ (Fig. 2) depending on the weather (Hjernquist \& Hjernquist, 1974).

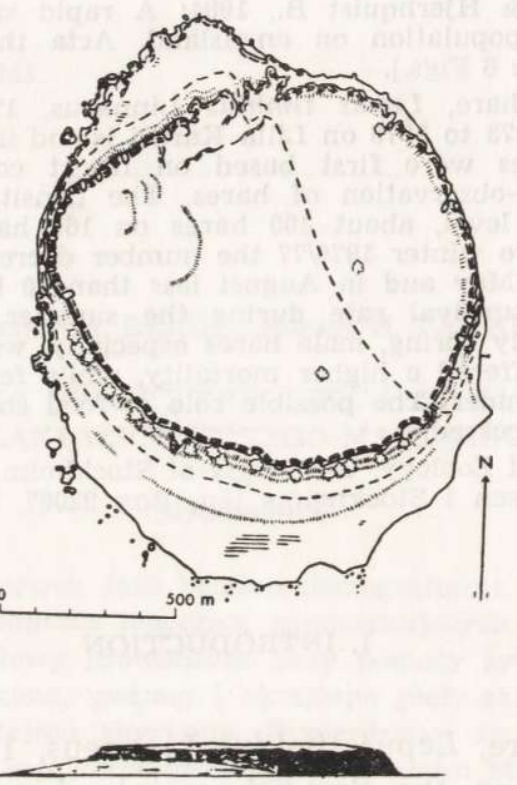

Fig. 1. Map over the Lilla Karlsö island. Dotted line shows the fixed observation route.

The crop value for 1977, the year of the decline, was not exceptionally low, 1.0 compared to previous years, 0.9 and 1.4 (Fig. 2). The vegetation can probably withstand a grazing pressure of 1.4 sheep per productive ha during the summer (Hjernquist \& Hjernquist, 1974) but in 1977 grazing pressure was 0.9 ewes per productive ha lasting for about ten months. The joint grazing by sheep and hares leads to overgrazing. According to Hjernquist \& Hjernquist (1974) there is a clear competition for food between hares and sheep.

Since at least 1725 hares have been released on the two Karlsö islands for hunting. In 188219 mountain hares caught on a nearby island were let out on Stora Karlsö island. Ten years later, in 1891, 237 animals were shot. In 1942, the hare population, which earlier was estimated at some 250-350 animals (Wahlin, 1945), was reduced to a very low density when foxes appeared on the island. Many hares then emigrated across the ice $(4.5 \mathrm{~km})$, and 50 hares arrived, according to Wahlin (1942), to the Lilla Karlsö island in January 1942. At that time the island had been without hares for over one hundred years. Since 1942 hunting has been irregular and not occurred after 1972. 
The winters $1972 / 73$ to $1974 / 75$ were all mild with $0-8$ days of snow cover, but winters $1975 / 76$ to $1977 / 78$ were cold with $36-50$ days snow (Fig. 3). Since the island is very exposed to wind, the snow surface becomes very hard, making access to the vegetation difficult for the hares.

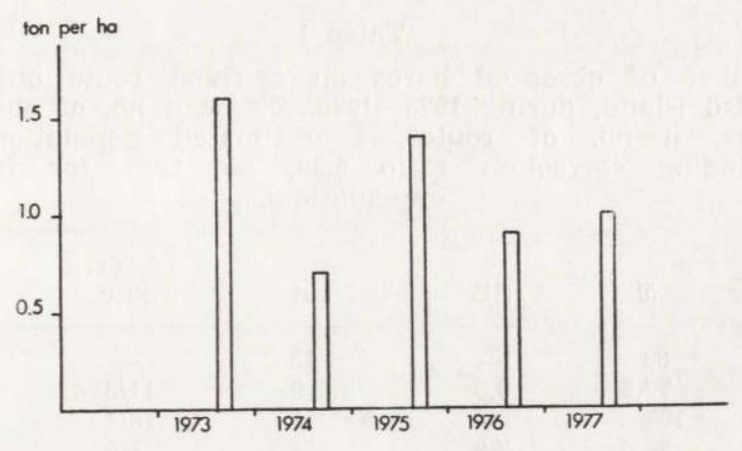

Fig. 2. Vegetation productivity as ton per ha per year on Lilla Karlsö island.

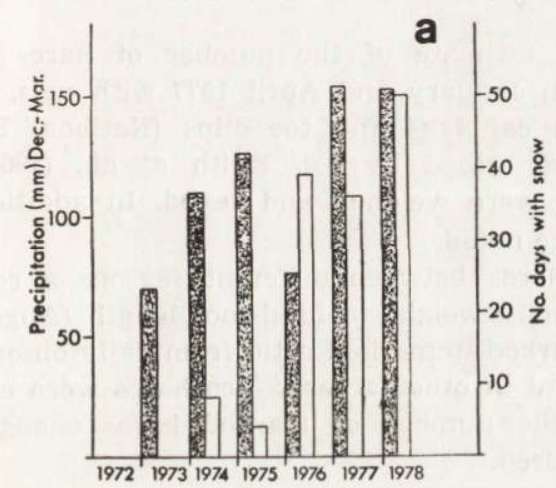

b

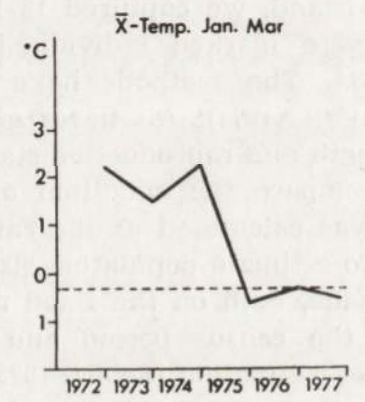

Fig. 3a. Precipitation ( $\mathrm{mm}$ ) during December to March (dark bars), and no. of days with snow cover (light bars) on Stora Karlsö island (SMHI).

Fig. 3b. Mean temperature during January to March on Stora Karlsö island, and 30 -years mean temperature (dotted line) (SMHI).

\section{METHODS}

To get an index of hare density on the island, systematic observations were made during the spring from 1973 to 1978. The observer walked a fixed route around the island (about $3 \mathrm{~km}$, Fig. 1) and recorded all adult hares encountered, juveniles excluded. The observations during one season were made by $2-3$ persons, and in total 5 persons. The observation periods are comparable in length and date (Table 1), and no significant differences were found between the observations made by the five observers, time of the day or weather conditions, during 1974, 1976 and 1977 (analysis of variance). Dead hares were also counted and each carcass was removed over the whole island. 
Hares that died during autumn, winter or early spring were found during the spring routes (to April), while hares that died during late spring or summer were found during the summer routes. Since carcasses were counted not only on the systematic routes, but also by the reserve keepers the whole summer through, it is assumed that dead hares were found with an equally high probability.

Table 1

Number of observed hares on a fixed route on Lilla Karlsö island, during $1973-1978 . \bar{x}=$ mean no. of observed hares, $n=$ no. of routes, $\hat{\mathrm{N}}=$ estimated population no. (including correction ratio 5.39, see text for further explanation).

\begin{tabular}{lclrcc}
\hline Year & $\bar{x}$ & SE & n & $\begin{array}{c}\text { Aver. } \\
\text { date }\end{array}$ & $\hat{\mathrm{N}}$ \\
\hline 1973 & 83 & $\overline{-}$ & 13 & - & 447 \\
1974 & 70.2 & 9.6 & 9 & $11 / 3$ & 378 \\
1975 & 107 & $\overline{7.9}$ & 1 & $18 / 4$ & 577 \\
1976 & 73.0 & 7.9 & $1 / 5$ & 393 \\
$1977 \mathrm{a}$ & 25.0 & 1.6 & 17 & $2 / 5$ & $(123)$ \\
$1977 \mathrm{~b}$ & 1.00 & 0.53 & 7 & $25 / 9$ & 5.4 \\
1978 & 0.86 & 0.26 & 7 & $29 / 4$ & 4.6 \\
\hline
\end{tabular}

In order to calculate an unbiased estimate of the number of hares present on the island, we captured 18 hares in January and April 1977 with nets. All the hares were marked individually with ear tags and toe clips (National Band \& Tag Co.). The methods have been described by e.g. Keith et al., (1968) and Angerbjörn (1977). All hares captured were weighed and sexed. In addition hind foot length and reproductive status were noted.

To compare the condition of the hares between different seasons a condition index was calculated as the ratio of body weight to hind-foot length (Angerbjörn, 1979). To estimate population size, a marked-unmarked ratio from daily observations were made, both on the fixed route and in other areas. Since hares were captured during the census period and thus the number of marked hares changed, the Schnabel estimation (Seber, 1973) was used.

The ratio of the estimated number of hares to the number of observed hares was calculated for January (ratio: 5.35) and April 1977 (ratio: 5.42). The average, 5.39 , was used to correct earlier observations (Table 1) for estimating the number of hares. There is a high correlation between number of observed hares and unbiased estimates of different densities on other islands (Angerbjörn unpubl.).

In most statistical analyses, methods and abbreviations from Sokal and Rohlf (1969) have been used.

\section{RESULTS}

A regression analysis between number of observed hares over the whole observation period and time was made for each year to estimate the mortality rate (in the test - the slope, Caughley 1977 p. 151) during the observation period. Since no mortality was found in any year (Table 2), we conclude that the average number of observed hares may 
be used as an estimate of the density for the period. However, there was a tendency for a decline in spring 1976 and for the marked hares in spring 1977 . The number of observed hares (Table 1) was significantly

Table 2

Regression analysis of In no. observed hares in relation to time in days, during the different periods of observation, 1974-1977, $t$-test for different slope (regression coefficient $b), b \neq 0$, that is statistically significant mortality during the period (Coughley 1977). $\mathrm{n}=$ no. of routes, $r^{2}=$ coeff. of determination.

\begin{tabular}{lccccc}
\hline Year & $r^{2}$ & $b$ & $\mathrm{n}$ & $t$ & $P$ \\
\hline 1974 & 0.06 & 0.008 & 9 & 0.69 & $P>0.05$ \\
1976 & 0.86 & -0.03 & 4 & -3.76 & $0.10>P>0.05$ \\
$1977 \mathrm{a}$ & 0.07 & -0.002 & 18 & -1.08 & $P>0.2$ total obs. \\
$1977 \mathrm{~b}$ & 0.20 & -0.02 & 16 & -1.91 & $0.10>P>0.05$ marked obs. \\
\hline
\end{tabular}

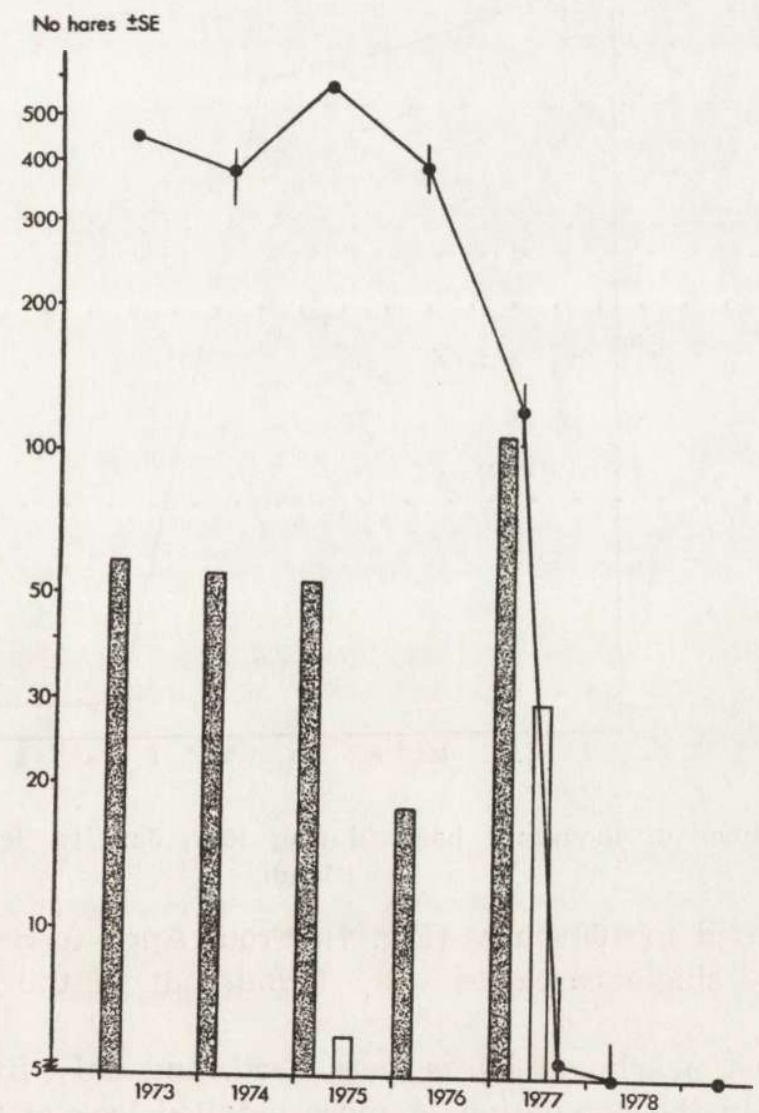

Fig. 4. Number of mountain hares, and no. of carcasses found, dark bars during winter and spring, light bars during the summer. 
lower (analysis of variance, Neuman-Keul test, $\alpha=0.05$ ) in 1977 than in 1974 and 1976.

According to Figure 4 the population has remained fairly stable at a very high level for a couple of years. After the winter 1975/76, which was the first with snow since 1970/71 (Fig. 3), there was a nonsignificant tendency for a decline in density. The following winter, 1976/77, was also severe with snow and cold weather. In January 1977, the density

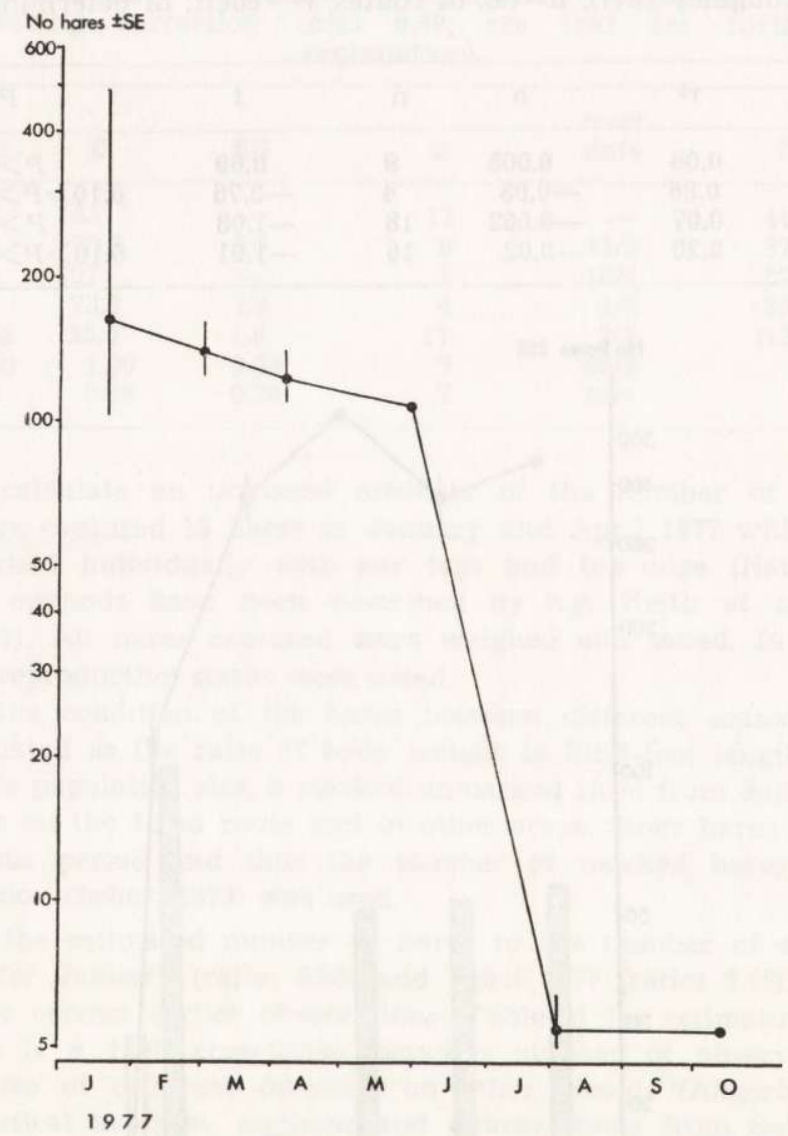

Fig. 5. Number of mountain hares during 1977, Jan. to Sept. (on Lilla Karlsö island).

had decreased to 160 hares (Fig. 4). From April to September normally no or only single carcasses were found, but in the summer 1977, we found 29 .

In August nearly all hares were dead, and only five were estimated to remain in the population. A more detailed look at the density during spring 1977 (Fig. 5) also shows a very sharp decline in June and July. In January, week 3, the population size was 162 and in May, week 22, 
107. From this level the population decreased to 5 hares in August, week 31. This indicates that the mortality rate from Table 3 is underestimated. If the mortality rate is constant during June and July the monthly mortality rate based on population densities should instead be 0.66 .

During the years of 1979,1980 and 1981, hares remained on the island in very low numbers. In 1982, however, there were more observations of hares, which could be a sign of a small increase in hare density.

\section{Table 3}

Mortality rate $q_{m}$ (Caughley, 1977) and survival values during spring 1977 , based on number of dead hares found.

\begin{tabular}{lcccc}
\hline \multirow{2}{*}{ Time } & \multicolumn{2}{c}{ Marked hares } & Survival \\
\cline { 2 - 3 } & Total & Dead & & $\begin{array}{c}\text { Mortality } q_{m} \\
\text { rate per months }\end{array}$ \\
\hline Feb.-Mar. & 9 & 2 & 0.78 & 0.11 \\
Apr.-May & 16 & 2 & 0.87 & 0.07 \\
Jun.-Jul. & 14 & 7 & 0.50 & 0.25 \\
Total & 18 & $11^{11}$ & 0.34 & 0.15 \\
\hline
\end{tabular}

${ }^{1}$ Later, in 1980 , two more marked hares were found.

Table 4

Analysis of variance of condition index, body weight over hind-foot length, in January and April 1977.

\begin{tabular}{llll}
\hline & \multicolumn{2}{l}{ Average condition index } & \\
\cline { 2 - 3 } & Males & Females & \\
\hline Jan. & 0.168 & 0.198 & $F(1.13)=0.62$ NS $^{1}$ \\
Apr. & 0.171 & $0.211^{2}$ & \\
\hline & $F(1.13)=12.4$ & & Interaction \\
& $P<0.01$ & & $F(1.13)=0.25 \mathrm{NS}$ \\
\hline
\end{tabular}

$1 \mathrm{NS}=$ non significant results at $P>0.05$ level.

2 The females were pregnant in April.

The mortality rate in Table 3 is based on the number of marked hare : found dead, compared to the total number of marked hares. The monthly mortality rate during spring 1977 was fairly constant from February to May. However, in the next two month period, June-July, the mortality rate increased to 0.25 per month. Since these figures assume that all marked dead hares should be found within a month, this is probably an underestimation.

There were no significant differences in the condition index between hares captured in January and April 1977 (Table 4). But the only two recaptures in April of hares marked in January, a male and a female, 
both showed a body weight decrease. The male decreased from 2.4 to $2.0 \mathrm{~kg}$ and the female from 3.4 to 3.3 despite that she was pregnant in April. All females were pregnant in April $(n=5)$, and all males $(n=5)$ were in reproductive phase as is normal for this time of the year, although the males had small testes. Moreover, juvenile hares were observed in June, but only very few, and not in the high numbers as in previous years.

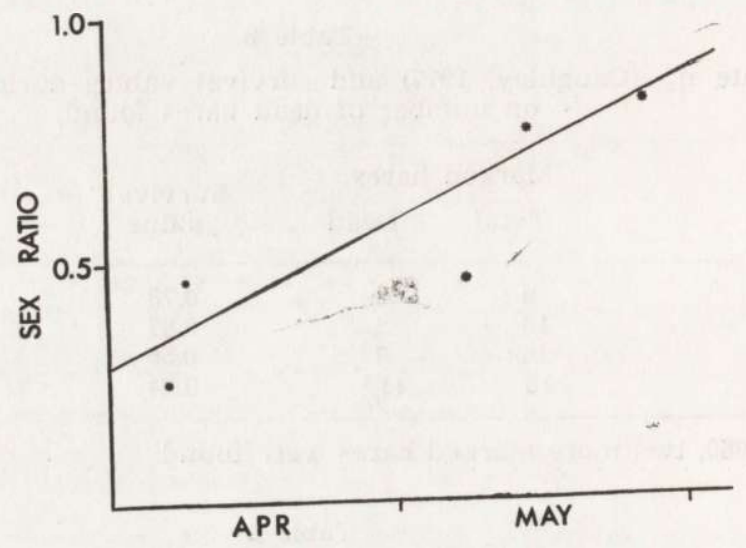

Fig. 6. The linear trend in sex ratio (males of total), based on observations of hares during spring 1977. The slope is significantly different from $0 \quad(P=0.03$, Snedecorand Cochran, p. 206, 1980), $y=0.01 x+0.32$.

Table 5

Endoparasites on mountain hares $(n=$ no. of hares) on Lilla Karlsö island and on mainland (Burgaz, 1970).

\begin{tabular}{|c|c|c|c|c|c|c|}
\hline \multirow[t]{2}{*}{ Species } & \multicolumn{2}{|c|}{$\begin{array}{l}\text { Mainland }{ }^{1} \\
1970\end{array}$} & \multicolumn{2}{|c|}{$\begin{array}{l}\text { Lilla Karlsö }{ }^{1} \\
1970\end{array}$} & \multicolumn{2}{|c|}{$\begin{array}{c}\text { Lilla Karlsö }^{2} \\
1973-1977\end{array}$} \\
\hline & $\%$ & $\mathrm{n}$ & $\%$ & $\mathrm{n}$ & $\%$ & $\mathrm{n}$ \\
\hline Eimeria spp. & 63 & (12) & 63 & (16) & 100 & (6) \\
\hline $\begin{array}{l}\text { Dicocoelum } \\
\text { dendriticum }\end{array}$ & 0 & (12) & 25 & (16) & 0 & (6) \\
\hline Andrya spp. & 0 & (12) & 33 & (30) & 33 & (6) \\
\hline Cittotaenia spp. & 11 & (12) & 33 & (30) & 0 & (6) \\
\hline $\begin{array}{l}\text { Graphidium } \\
\text { strigosum }\end{array}$ & 0 & (12) & 10 & (30) & 0 & (6) \\
\hline $\begin{array}{l}\text { Trichostrongylus } \\
\text { retortaeformis }\end{array}$ & 99 & (12) & 90 & $(30)$ & 83 & (6) \\
\hline Trichurus leporis & 0 & (12) & 20 & (30) & 33 & (6) \\
\hline $\begin{array}{l}\text { Protostrongylus } \\
\text { pulmonalis }\end{array}$ & 50 & (12) & 100 & (30) & 89 & (9) \\
\hline Fasciola hepatica & 0 & (12) & 6 & (16) & 0 & (6) \\
\hline
\end{tabular}

1 From Burgaz, 1970.

2 In this study all the examinations of hares from 1973-1977 have been made by National Veterinary Institute, Uppsala. 
Fig. 6 shows a significant linear trend (Snedecor \& Cochran 1980, p. 206, $p=0.03)$ in sex ratio ( $M$ : total) of observed marked hares during the spring. This trend is underlined by the sex ratio in captures, i.e. 0.33 in January and 0.55 in mid April.

Only a few hares were examined for parasites. They had all severe endo-parasitic infestations (Table 5), especially lungworms. Compared with a previous study on endo-parasites by Burgaz (1970) on Lilla Karlsö island, there are no differences (Table 5).

Both Ixodes ricinus and Haemaphysalis punctata have earlier been found on Stora Karlsö island (Schulze, 1939). All hares captured were heavily infected by ticks, both in January and April, probably primarily by $I$. ricinus. On one occasion we found a leveret with 50 ticks around one eye.

\section{DISCUSSION}

The basic pattern in adult mortality for the Lepus genus seems to be a rather high mortality in winter, and in decline years even in spring. Flux (1970) describes adult mortality for mountain hares as highest in February to May. In the snowshoe hare, L. americanus, Keith \& Windberg (1978) concluded that the greatest adult mortality occurs in winter, even during years of a rapid decline.

The hare mortality on Lilla Karlsö island before January 1977, and through the spring, seems to be normal in decrease years for mountain hares. Contrasting to other studies, however, the survival rate for adults is lowest in the summer, in July 0.75 or even as low as 0.34 . Usually, there is no adult mortality for mountain hares during June to October at all (Angerbjörn, unpubl.).

In a study with manipulated high densities on islands, Windberg and Keith (1976) calculated monthly adult survival rates for snowshoe hares during the summers of three different years. In unmanipulated areas these were $0.94,0.84$ and 0.78 , with the third survival rate after a winter with a crash. On manipulated high density islands the survival rates were $0.88,0.80$ and 0.85 (the 3 rd value adjusted for abnormal predation). In another island study of European hare (L. europeus) Abildgård et al. (1972) found that adult hares have an average monthly mortality of 4 to $5 \%$ with no clear differences between seasons.

Studies on the mountain hare and the snowshoe hare show a pronounced decrease in average body weight during winter and spring declines (Keith \& Windberg, 1978; Angerbjörn, 1981). During our study we could not show a similar trend. In an experimental snowshoe hare study (Windberg \& Keith, 1976), surviving adults in high density pop- 
ulations with limited food, did not respond by loss of body weight, but juvenile survival was markedly lower. On Lilla Karlsö island, especially the males had very low body weights and condition indices. Some of them showed clear signs of starvation. Comparing the average index value in January 1977 from Lilla Karlsö with an island without a crash (Angerbjörn, 1979) at the same time, one obtains 0.168 and 0.198 for males and 0.198 and 0.193 for females.

The linear trend in sex ratio, i.e. relatively fewer males observed during the spring, suggests a higher male mortality in early spring. Thus, the male loss in condition during the winter is followed by a higher male mortality during the spring. Following the shift in the sex ratio, the females should in contrary suffer a higher mortality in the early summer.

All female hares in this study were pregnant in the spring, but only a few leverets were observed in May to June. Hewson (1976) discusses the possibility that females could die after the birth on early litters in a year of sharp decline. The energy necessary for reproduction and lactation could decrease the condition of the female hares (see e.g. Microtus arvalis by Stenseth et al., 1980).

There are many thoughts of what regulates hare populations, through intrinsic (e.g. Christian et al., 1965; Chitty, 1967) or extrinsic factors such as food, predation and diseases (e.g. Lack, 1954; Wagner \& Stoddart, 1972; Keith, 1974). In this paper we will only discuss the extrinsic effects of food in winter and summer, predation i.e. goshawk (Accipiter gentilis) and golden eagle (Aguila chrysaetos), and parasites and disease.

The hypothesis that predators caused the summer decline is not likely, since not a single bird of prey were observed although observers and reserve keepers were present on the island the whole summer. Predators could, however, have been involved in the winter decline.

Facts that favour the hypothesis of winter food shortage are: the severe winter with vegetation covered by snow, and the obvious density decline in hares before January. Furthermore the hares seem to have been in poor condition in January, although the highest mortality is measured in the summer. But the mortality pattern does not differ compared to other islands where no crash did take place (Angerbjörn 1981, and unpubl.).

It is also possible that the food in spring is a limiting factor: 1977 had the lowest mean temperature for April this century. There could be severe competition for available food between hares and sheep (Hjernquist \& Hjernquist, 1974; Hewson, 1976). One hundred sheep were let out in early April, before the vegetation season started, and seven ewes died that spring compared to not more than one in previous years. 
The role played by parasities and diseases in this population is unclear. All hares captured were infested by ticks, Ixodes ricinus or Haemaphysalis punctata. Ticks of these species are known to infest hares of the Lepus genus in high numbers (Mohr \& Lord, 1960; Wasylik, 1965; Nosek, 1971a, 1971b; Kadulski \& Dobryńczuk, 1976). The ticks show a clear seasonality, with peaks in infestation in spring and early summer. Ticks are also vector s of encephalitis virus of different types that can infect hares (Yuill \& Hanson, 1964; Nosek, 1971a, 1971b), and may cause a higher mortality (Hoff et al., 1969; Yuill et al., 1969). There are yearly infections of Russian spring and summer encephalitis (RSSE) from the tick I. ricinus on man on the two Karlsö islands. Therefore, it seem; likely that tick borne virus could have caused some of the observed increased summer mortality of the hares on the Lilla Karlsö island.

It is not possible to sort out a single factor that causes the decline, but one explanation of the above results could be: After a severe winter with food shortage, the hares had to compete for food with the sheep during spring. Their poor body condition made them susceptible to ticks and diseases that thereby lowered their possibilities for recovering during the summer.

Acknowledgements: This study was supported by grants from the Swedish society for the conservation of nature and the Helge Axson Johnson foundation. We would like to thank everybody that helped us with the field work, especially L. Lundgren gave us unvaluable help. L. Chapman, O. Grönwall, H. Ostborn-Ahnlund and other members of the mammal group in Stockholm and Drs. N. C. Stenseth and C. Wiklund gave us valuable comments on the manuscript. We are also grateful to B. Mayrhofer who kindly draw the figures, to L. Chapman for correcting the English and to the National Veterinary Institute for the parasitic analyses.

\section{REFERENCES}

1. Abildgård F., Andersen J. \& Barndorff-Nielsen O., 1972: The hare population (Lepus europaeus Pallas) of Illumø island, Denmark. A report on the analysis of the data from 1957-1970. Danish Rev. Game Biol., 6: 1-30.

2. Angerbjörn A., 1977: A study of an extremely dense population of mountain hares (Lepus timidus), on an island off the west coast of Sweden. Zool. Revy, 39: 119-130. [In Swedish with English summary].

3. Angerbjörn A., 1981: Winter food as a limiting factor of dense mountain hare population on islands, a comparative study. [In: Myers K., MacInnes C. D., Eds., "Proc. World Lagomorph Conf."]: 529-535. Guelph, Ontario.

4. Burgaz I., 1970: A report on the presence of endoparasites in Lepus timidus and Lepus europaeus in Sweden. Trans. Inter. Congr. Game Biol., 9: 628-632.

5. Caughley G., 1977: Analysis of vertebrate populations. John Wiley \& Sons: 1-234. London.

6. Chitty D., 1967: The natural selection of self-regulatory behaviour in animal populations. Proc. Ecol. Soc. Aust., 2: 51-78.

7. Christian J. J., Lloyd J. A. \& Davis D. E., 1965: The role of endocrines in 
the self-regulation of mammalian populations. Rec. Progr. Horm. Res., 21: $501-571$.

8. Flux J. E. C., 1970: Life history of the mountain hare (Lepus timidus scoticus) in north-east Scotland. J. Zool., Lond., 161: 75-123.

9. Hardy J. L., Milby M. M., Wright M. E., Beck A. J., Presser S. B. \& Bruen J. P., 1977: Natural and experimental arboviral infections in a population of blacktailed jackrabbits along the Sacramento river in Buttee county, California (1971-1974). J. Wildl. Dis., 13: 383-392.

10. Hewson R., 1965: Population changes in the mountain hare, Lepus timidus L. J. Anim. Ecol., 34: 587-600.

11. Hewson R., 1976: A population study of mountain hares (Lepus timidus) in north-east Scotland from 1956-1969. J. Anim. Ecol., 45: 395-414.

12. Hjernquist B. \& Hjernquist A., 1974: Vegetationen pa Lilla Karlsö produktionsundersökning och inventering $\mathrm{i}$ ett traditionellt farbeteslandskap. Dept. of Botany, Univ. of Stockholm: 1-102.

13. Hoff G. L., Yuill T. M., Iversen J. O. \& Hanson R. P., 1969: Snowshoe hares and the California encephalitis virus group in Alberta 1961-1968. Bull. Wildl Dis. Assoc., 5: 254-259.

14. Häkkinen I. \& Jokinen M., 1981: Population dynamics of the mountain hare, Lepus timidus, on an island in the outer archipelago of Finland in 1971-1978 [In: Myers K., MacInnes C. D., eds. "Proc. World Lagomorph Conf."]: 469-477. Guelph, Ontario.

15. Kadulski S. \& Dobryńczuk J., 1976: Observations on the ectoparasites on the European hare. [In: "Ecology and management of European hare populations", Z. Pielowski, Z. Pucek, eds.]. Państw. Wyd. Roln. i Leśne: 177-183. Warszawa.

16. Keith L. B., 1974: Some features of population dynamics in mammals. Trans. XI Congr. Int. Union Game Biol., 11: 17-58.

17. Keith L. B. Meslow E. L. \& Rongstad O. J., 1968: Techniques for snowshoe hare population studies. J. Wildl. Manage., 32: 801-812.

18. Keith L. B. \& Windberg L. A., 1978: A demographic analysis of the snowshoe hare cycle. Wildl. Monogr., 58.

19. Lack D. L., 1954: The natural regulation of animal numbers. Clarendon Press: 1-343. Oxford.

20. Lindlöf B. \& Lemnell P. A., 1981: Differences in island and mainland populations of mountain hare. [In: Myers K., MacInnes C. D., eds. "Proc. World Lagomorph Conf."]. 478-485. Guelph, Ontario.

21. Mohr C. O. \& Lord R. D., 1960: Relation of ectoparasite populations to rabbit populations in northern Illinois. J. Wildl. Manage., 24: 290-297.

22. Nosek J., 1971a: The ecology, bionomics and behaviour of Haemaphysalis (Haemaphysalis) concinna tick. Z. Parasitenk., 36: 233-241.

23. Nosek J., 1971b: The ecology, bionomics and behavior of Haemaphysalis (Aboimisalis) punctata tick in central Europe. Z. Parasitenk., 37: 198-210.

24. Schulze P., 1939: Über schwedische, rumänische und nordamerikanische Formen von Ixodes ricinus (L.) und über Haemaphysalis punctata Can. et Fanz. f. autumnalis P. Sch. Ark. Zool., 31: A, 18.

25. Seber G. A. F., 1973: The estimation of animal abundance and related parameters. Griffin: 1-506. London.

26. Snedecor G. W. \& Cochran W. G., 1980: Statistical methods. 1-519. 7th ed Iowa. 
27. Sokal R. R. \& Rohlf F. J., 1973: Introduction to biostatistics. Freeman and Co.: 1 -368. San Francisco.

28. Stenseth N. C., Framstad E., Migula P., Trojan P. \& Wojciechowska-Trojan B., 1980: Energy models for the common vole Microtus arvalis: energy as a limiting resource for reproductive output. Oikos, 34: 1-22.

29. Wagner F. H. \& Stoddart L. C., 1972: Influence of coyote predation on blacktailed jackrabbit populations in Utah. J. Wildl. Manage., 36: 329-342.

30. Wahlin B. J. O., 1942: Ett besök pa Lilla Karlsö vintern 1942. Fauna \& Flora, 37, 2.

31. Wahlin B. J. O., 1945: Vegetationen pa Lilla Karlsö. I. Lövskogs-fragment. Botaniska notiser, 1945: 91-100.

32. Wasylik A., 1965: Studies of the European hare. VIII. Dynamics of occurrence of Listrophorus gibbus Pagenstecher, 1862. Acta theriol., 10: 27-54.

33. Watson A., Hewson R., Jenkins D. \& Parr R., 1973: Population densities of mountain hare compared with red grouse on Scottish moors. Oikos, 24: $225-230$.

34. Windberg L. A. \& Keith L. B., 1976: Snowshoe hare population response to artificial high densities. J. Mammal., 57: 523-553.

35. Yuill T. M. \& Hanson R. P., 1964: Serologic evidence of California encephalitis virus and western equine encephalitis virus in showshoe hares. Zoonoses Res., 3: 153-164.

36. Yuill T. M., Iversen J. O. \& Hanson R. P., 1969: Evidence of arbovirus infection in a population of snowshoe hares: A possible mortality factor. Bull. Wildl. Dis. Assoc., 5: 248-253.

Accepted, November 16, 1983.

\section{Anders ANGERBJÖRN i Björn HJERNQUIST}

\section{GWAETOWNY LETNI SPADEK POPULACJI WYSPOWEJ LEPUS TIMIDUS}

\section{Streszczenie}

Pop̣ulację zajęcy żyjącą na wyspie Lilla Karlsö, na Bałtyku, obserwowano w latach 1973-1978 (Tabela 1, 2; Ryc. 1). Wykonywano również w tym czasie obserwacje meteorologiczne (temperatura, opady) oraz szacowano ilość dostępnego dla zajęcy pokarmu (Ryc. 2, 3a, b). Ocenę zagęszczenia Lepus timidus oparto na bezpośrednim liczeniu oraz na znakowaniu i obserwacji znakowanych sztuk. Zagęszczenie było właściwie stałe, na bardzo wysokim poziomie, około 400 zajęcy na $1 \in 0$ ha $w$ kolejnych latach. W ciągu surowej zimy 1976/1977 liczba ich spadła do 162 zajęcy w styczniu, $107 \mathrm{w}$ maju a w sierpniu pozostało już mniej niż 10 sziuk (Ryc. 4, 5). Sredni miesięczny poziom przeżywania był zatem w lecie niższy niż 0.75 (Tabela 3 ; Ryc. 6). Wczesną wiosną, szczególnie samce zajęcy, były $w$ złej kondycji i prawdopodobnie masowo padały, podczas gdy samice prawdopodobnie padaly $\mathrm{w}$ ciągu wczesnego lata (Tabela 4). Przedyskutowano możliwość wpływu niedostatku pokarmu i inwazji pasożytów, na zaistniałą sytua:ję. 